\title{
Assessment of Fertilising Properties of a Solid Digestate in Comparison with Undigested Cattle Slurry Applied to an Acidic Soil
}

\author{
Carmo Horta* ${ }^{*}$, João Paulo Carneiro \\ Research Centre for Natural Resources, Environment and Society, Polytechnic Institute of Castelo Banco, CERNAS/IPCB, \\ Castelo Branco, Portugal \\ Email: *carmoh@ipcb.pt
}

How to cite this paper: Horta, C. and Carneiro, J.P. (2020) Assessment of Fertilising Properties of a Solid Digestate in Comparison with Undigested Cattle Slurry Applied to an Acidic Soil. Open Journal of Soil Science, 10, 307-325.

https://doi.org/10.4236/ojss.2020.108017

Received: June 23, 2020

Accepted: August 16, 2020

Published: August 19, 2020

Copyright () 2020 by author(s) and Scientific Research Publishing Inc. This work is licensed under the Creative Commons Attribution International License (CC BY 4.0).

http://creativecommons.org/licenses/by/4.0/

\begin{abstract}
The use of digestates or cattle slurries as fertilisers could contribute to the recycling of nutrients and organic matter, thus meeting the goals of the circular economy in agriculture. This work aims at evaluating the fertilising properties of a solid digestate (DG) in comparison with undigested cattle slurry (CS) and mineral fertilisation (MF). The experiment was performed in pots with ryegrass (Lolium multiflorum Lam.) grown in an acidic soil during a 163 days crop cycle. The results showed that throughout the crop cycle neither DG nor CS increased soil organic matter. DG significantly increased $(P<0.001)$ the sum of the soil exchangeable bases and soil $\mathrm{P}$ availability compared with CS or MF. Also, DG significantly increased $(\mathrm{P}<0.05)$ the apparent $\mathrm{P}$ recovery of ryegrass (43\%) compared with MF (27\%). In the first cut, the ryegrass yield was higher in DG and CS than in MF, decreasing in the second and third cuts as a consequence of a decrease in $\mathrm{N}$ availability. Nevertheless, the fertilisation with DG or CS could replace the half amount of mineral $\mathrm{N}$ fertilisation, without a significant decrease in the ryegrass forage production. In addition, DG enables greater efficiency in the use of $\mathrm{P}$ than CS or MF.
\end{abstract}

\section{Keywords}

Agronomic Efficiency, Biogas, Nitrogen Use Efficiency, Phosphorus Use Efficiency, Sustainable Agriculture

\section{Introduction}

Livestock effluents, manures and slurries, are commonly used as fertilisers in agriculture as soil improvers or providing nutrients for crop growth. These effluents could also be used as feedstock for anaerobic digestion (AD) to obtain bio- 
gas principally methane $\left(\mathrm{CH}_{4}\right)$ with the production of a by-product called digestate which is biological stable, and free of pathogens and with fertiliser properties [1] [2].

Turning livestock effluents and other organic wastes into a renewable energy resource such as the production of biogas or biomethane offers an opportunity to 1) continuously use and reuse organic waste, 2) produce digestate with fertilising properties and 3) decrease greenhouse gas emissions. In Europe the production potential for biogas and biomethane by feedstock sources in 2018 was 110 Mtoe [3]. In some countries of the Mediterranean region in EU the biogas production from livestock manures represents less than $1 \%$ of its potential [4] [5]. Currently the EU policies and strategies have been increased efforts to push the biogas production as part of the energy sector. So, in the next years it is expected an increase in digestate production and consequently the need of deeper knowledge about its good agricultural management practices.

Compared to undigested slurry the solid fraction of the digestate (obtained after centrifugation, pressing or drying the digestate sludge) has higher amounts of C (370 - $420 \mathrm{~g} \cdot \mathrm{kg}^{-1}$ of DM vs $\left.\sim 26 \mathrm{~g} \cdot \mathrm{L}^{-1}\right)$ and of OM (550 - $860 \mathrm{~g} \cdot \mathrm{kg}^{-1}$ of DM vs $\sim 44 \mathrm{~g} \cdot \mathrm{L}^{-1}$ ) [6] and higher proportion of N-organic in relation to the total-N. Also, changes in the biochemical composition of the OM during the $\mathrm{AD}$ lead to more recalcitrant $\mathrm{C}-\mathrm{OM}$ fractions in the digestates (lignin-like material, complex lipids, and steroids) than in the starting mixtures [7] and those molecules have been reported to be humus precursors [8].

Although the fertilising properties of the solid digestate are recognised [5] [7] [9] [10] [11] [12] [13] there are some contradictory results. For example, Thomas et al. [14], did not found after five seasons significant differences in the total soil carbon content between the treatments with application of solid digestate, compost or farmyard manure despite of the $\mathrm{C} / \mathrm{N}$ ratio of 24 of the solid digestate. In turn Liedl et al. [15] observed an increase in soil OM and in the available $\mathrm{P}$ over a four-year period of solid digestate application. In addition, these authors observed lower yields in treatments with solid digestate application which they attributed to a higher immobilisation of inorganic $\mathrm{N}$ compared with treatments with compost or farmyard manure application. Regarding the fertilising properties of undigested cattle slurry, it is mainly a source of crop nutrients in dissolved forms in particular nitrogen [16]. It has low concentration of nutrients and also of dry matter $\left(71 \pm 13 \mathrm{~g} \cdot \mathrm{L}^{-1}\right)$ [17], and its high-water content makes transport and application costs more expensive than the solid fraction of the digestate. To prevent the risks of ammonia emissions both, digestate and undigested slurry, must be incorporated into soil. Nevertheless, undigested slurry must be applied by subsurface injection with the need of specific equipment and of extra power consuming [9] [18]. In addition, the environmental impacts of the application of undigested slurry into soil on the eutrophication of waterbodies and on greenhouse gas emissions could be minimised by its use as feedstock for anaerobic digestion. The experiment of this work was done considering the need to assess the added value of the agricultural use of digestate over undi- 
gested slurries in relation to their fertilising properties (as sources of soil organic matter and/or source of crop nutrients) under Mediterranean conditions. We hypothesised that the in the short-term the fertilising effect of undigested slurry and the solid fraction of the digestate could be similar or even better for digestate. A pot experiment was carried out with ryegrass fertilised with a solid digestate obtained from cattle slurry or with undigested cattle slurry or a mineral fertilisation. The ryegrass was cut three times during the experiment, in order to provide data about the availability of $\mathrm{N}$ and $\mathrm{P}$ throughout the crop cycle. The fertilising properties in the short-term were evaluated by the soil chemical properties, ryegrass yield and nitrogen and phosphorus use efficiency indexes.

\section{Materials and Methods}

\subsection{Experimental Design}

To assess the agronomic effects of the digestate (DG) in comparison with undigested cattle slurry (CS) or with mineral fertilisation (MF) a pot experiment was carried out with annual ryegrass (Lolium multiflorum Lam., cv. Winter Star II) as plant test. The pots were placed outdoor under a glass cover $\left(39^{\circ} 49^{\prime} 25.9^{\prime \prime} \mathrm{N}\right.$ $7^{\circ} 27^{\prime} 07.5^{\prime \prime} \mathrm{W}$ ) from $29^{\text {th }}$ November 2018 to $19^{\text {th }}$ May 2019 at the Polytechnic Institute of Castelo Branco, Portugal. During the crop cycle the monthly means of air temperature ranged from $8.4^{\circ} \mathrm{C}$ to $18.4^{\circ} \mathrm{C}$. The soil used was a dystric regosol [19] developed on granitic rock in a Mediterranean climate. It was an acid $\left(\mathrm{pH}_{\mathrm{H} 2 \mathrm{O}}=5.1\right)$ sandy loam soil ( $8 \%$ clay, $18 \%$ silt and $74 \%$ sand), with medium cation exchange capacity $\left(12.5 \mathrm{cmol}_{\mathrm{c}} \cdot \mathrm{kg}^{-1}\right)$ compared with reference values (CEC $10.1-20.0 \mathrm{cmol}_{\mathrm{c}} \cdot \mathrm{kg}^{-1}$ ) of the method (ammonium acetate buffered at $\mathrm{pH} 7.0$; [20]), low levels of exchangeable $\mathrm{Ca}, \mathrm{Mg}$, and $\mathrm{Na}\left(2.0,0.67\right.$ and $0.09 \mathrm{cmol}_{\mathrm{c}} \cdot \mathrm{kg}^{-1}$ respectively). It had a medium content of organic matter $\left(27 \mathrm{~g} \cdot \mathrm{kg}^{-1}\right)$. The soil had also a low content of available P (8 $\mathrm{mg} \cdot \mathrm{kg}^{-1}$ of Olsen P), medium level of exchangeable $\mathrm{K}\left(0.3 \mathrm{cmol}_{c} \cdot \mathrm{kg}^{-1}\right)$ and a low degree of base saturation (20\%). In the Mediterranean region these soils are mainly used for rain-fed pastures and for cereal crops such as rye and barley.

The soil was sampled at $0-0.20 \mathrm{~m}$ depth, air dried and sieved through a $5 \mathrm{~mm}$ mesh and poured into plastic pots each one with $6 \mathrm{~kg}$ of capacity. The experiment was carried out during 170 days. Since the soil is poor in available P it was done treatments with and without mineral $\mathrm{P}$ fertilisation. The $\mathrm{P}$ fertilisation was done with single superphosphate (SSP) at a rate of $35 \mathrm{~kg} \mathrm{P} \mathrm{ha}^{-1}$ incorporated into the soil at the beginning of the experiment before sowing. The mineral nitrogen fertilisation was done with a total amount of $170 \mathrm{~kg} \mathrm{~N} \mathrm{ha}^{-1}$ the threshold level to soil $\mathrm{N}$ application from organic amendments by the Portuguese legislation [21]. So, the mineral $\mathrm{N}$ fertilisation was divided into three applications: $85 \mathrm{~kg} \mathrm{~N} \mathrm{ha}^{-1}$ at sowing and then $42.5 \mathrm{~kg} \mathrm{~N} \mathrm{ha}^{-1}$ as top-dressing after the first cut of the ryegrass and the remaining $42.5 \mathrm{~kg} \mathrm{~N} \mathrm{ha}^{-1}$ after the second cut. Concerning the $\mathrm{N}$ fertilisation through the organic amendments it was done by two different ways: 1) DG or CS were mixed with the soil one week before sowing using an amount 
corresponding to the full application of $170 \mathrm{~kg} \mathrm{~N} \mathrm{ha}^{-1}$ (No), in this case no more $\mathrm{N}$ was applied during the crop cycle and 2) DG or CS were mixed with the soil one week before sowing using an amount corresponding to the application of $85 \mathrm{~kg} \mathrm{~N} \mathrm{ha}^{-1}$ and then mineral $\mathrm{N}$ was applied at a rate of $42.5 \mathrm{~kg} \mathrm{~N} \mathrm{ha}^{-1}$ as top-dressing after the first cut of the ryegrass and the remaining $42.5 \mathrm{~kg} \mathrm{~N} \mathrm{ha}^{-1}$ after the second cut (NoNi). The mineral $\mathrm{N}$ was applied to soil in solution using ammonium nitrate $\left(\mathrm{NH}_{4} \mathrm{NO}_{3}\right)$ reagent p.a. The experiment consisted of a randomized block design with ten treatments each one with four replicates generating a total of 40 pots. The treatments used are referred in Table 1.

After DG and CS addition to soil at $29^{\text {th }}$ November 2018 , the soil was watered at $70 \%$ of the field capacity. After one week the ryegrass was sown with 60 seeds per pot. The cuts of the ryegrass were done at 71,111 and 163 days after sowing. The pots were watered throughout the crop cycle at $70 \%$ of the field capacity.

After each cut of ryegrass, dry-matter production was quantified and the concentration of $\mathrm{N}$ and $\mathrm{P}$ in dry matter was determined. Also, a soil sample of each pot was taken after the end of the experiment for soil analysis.

The agronomic effects of the organic amendments were assessed by 1) soil fertility properties, 2) crop yield (dry matter production) and 3 ) indexes of $\mathrm{N}$ and $\mathrm{P}$-use efficiency of the crop.

The indexes of $\mathrm{N}$ and P-use efficiency of the crop [22] [23] used were 1) $\mathrm{N}$ or $\mathrm{P}$ uptake, 2) apparent $\mathrm{N}$ or $\mathrm{P}$ recovery by crop (Equation (1)) and 3) agronomic efficiency of $\mathrm{N}$ or $\mathrm{P}$ (Equation (2)).

Table 1. Treatments used in the pot experiment.

\begin{tabular}{|c|c|c|c|c|c|}
\hline \multirow{3}{*}{ Treatments } & $\mathrm{N}$ organic $(\mathrm{No})$ & $\mathrm{N}$ inorganic $(\mathrm{Ni})$ & $\mathrm{N}$ inorganic $(\mathrm{Ni}$ & $\mathrm{N}$ inorganic $(\mathrm{Ni})$ & $\mathrm{P}$ inorganic $(\mathrm{Pi})$ \\
\hline & Before sowing & Before sowing & After $1^{\text {st }}$ cut & After $2^{\text {nd }}$ cut & Before sowing \\
\hline & \multicolumn{5}{|c|}{$\mathrm{kg} \cdot \mathrm{ha}^{-1}$} \\
\hline \multicolumn{6}{|c|}{ Control } \\
\hline NOP0 & 0 & 0 & 0 & 0 & 0 \\
\hline \multicolumn{6}{|c|}{ Mineral fertilisation } \\
\hline $\mathrm{NiPi}$ & & 85 & 42.5 & 42.5 & 35 \\
\hline \multicolumn{6}{|c|}{ Digestate } \\
\hline NoPi_DG & 170 & 0 & 0 & 0 & 35 \\
\hline No_DG & 170 & 0 & 0 & 0 & 0 \\
\hline NoNiPi_DG & 85 & & 42.5 & 42.5 & 35 \\
\hline NoNi_DG & 85 & 0 & 42.5 & 42.5 & 0 \\
\hline \multicolumn{6}{|c|}{ Cattle slurry } \\
\hline NoPi_CS & 170 & 0 & 0 & 0 & 35 \\
\hline No_CS & 170 & 0 & 0 & 0 & 0 \\
\hline NoNiPi_CS & 85 & & 42.5 & 42.5 & 35 \\
\hline NoNi_CS & 85 & 0 & 42.5 & 42.5 & 0 \\
\hline
\end{tabular}




$$
\text { Apparent } \mathrm{N} \text { or } \mathrm{P} \text { recovery by } \operatorname{crop}(\%)=\left[\left(U n-U_{c}\right) / F n\right] \times 100
$$

In Equation (1) $U$ is the uptake (mg $\mathrm{N}$ or $\mathrm{P} \mathrm{kg}^{-1}$ soil) with $(U n)$ or without $(U c)$ $\mathrm{N}$ or $\mathrm{P}$ fertilisation and $F n$ is the amount of $\mathrm{N}$ or $\mathrm{P}$ applied (mg $\mathrm{N}$ or $\mathrm{P} \mathrm{kg}^{-1}$ soil).

$$
\text { Agronomic efficiency, AE }\left(\mathrm{g} \mathrm{DMY} \mathrm{mg}^{-1} \mathrm{P}\right)=\left[\left(Y n-Y_{C}\right) / F n\right]
$$

In Equation (2) $Y$ is the dry matter yield ( $\mathrm{g}$ DMY kg-1 soil) with $(Y n)$ or without $(Y c) \mathrm{N}$ or $\mathrm{P}$ fertilisation and $F n$ is the amount of $\mathrm{N}$ or $\mathrm{P}$ applied $(\mathrm{mg} \mathrm{N}$ or $\mathrm{P}$ $\mathrm{kg}^{-1}$ soil).

In order to get a better understanding about the effects of the organic amendments on $\mathrm{P}$ availability the $\mathrm{P}$ recovery (Prec) by the Olsen method [24] (Equation (3)) was also calculated using the following ratio (units in $\mathrm{mg} \mathrm{P}^{-1}$ soil):

$$
\begin{aligned}
& \operatorname{Prec}(\%) \\
& =[(\text { Olsen P after the experimente }- \text { Initial Olsen P }) /(\text { Padded to soil })] \times 100
\end{aligned}
$$

\subsection{Analysis}

\section{Soil}

Soil samples were air dried, sieved $(<2 \mathrm{~mm})$ and analysed for textural class, organic matter, $\mathrm{pH}\left(\mathrm{H}_{2} \mathrm{O}\right)$, electrical conductivity (EC), available $\mathrm{P}$, and exchangeable bases ( $\mathrm{Ca}, \mathrm{Mg}, \mathrm{K}$ and $\mathrm{Na}$ ). The soil texture was evaluated by the particle size analysis using the pipet method [25]. The organic matter was analysed according to the procedure described in [26]. The $\mathrm{pH}$ was measured using a $\mathrm{pH}$ electrode in a 1:2.5 soil to solution ratio and the electrical conductivity with a conductivity meter in a 1:2 soil to water ratio suspension. The contents of the exchangeable bases $\mathrm{Ca}, \mathrm{Mg}, \mathrm{K}$ and $\mathrm{Na}$ were measured by atomic absorption spectrometer after extraction with a molar solution of $\mathrm{CH}_{3} \mathrm{COONH}_{4}$ buffered at $\mathrm{pH}$ 7.0. The Olsen $\mathrm{P}$ was used to evaluate plant available $\mathrm{P}$, which was determined according to Olsen et al. [24] and it was quantified by the method of Murphy and Riley [27].

\section{Ryegrass}

Shoots of rye grass of each treatment and cut were weighed for quantification of the biomass production (fresh matter) then they were dried at $65^{\circ} \mathrm{C}$ for $48 \mathrm{~h}$ and weighed again for the quantification of crop yield on a dry matter production basis. The dried plants were grounded in a ball mill, sieved at a $0.5 \mathrm{~mm}$-mesh sieve and then were placed in a muffle furnace at a temperature of $480^{\circ} \mathrm{C}$ for 16 $\mathrm{h}$ to obtain the ashes. Total $\mathrm{P}$ was measured after digestion of the ashes with hydrochloric acid solution ( $\mathrm{HCl} 20 \%$, v/v). P was quantified by spectrophotometry at a wavelength of $470 \mathrm{~nm}$. Nitrogen was quantified by the Kjeldahl procedure $\left(\mathrm{N}_{\mathrm{k}}\right)$ after each cut and before drying the shoots.

\section{Organic amendments}

The organic amendments, solid digestate (DG) and undigested cattle slurry (CS) were characterised for moisture content by the gravimetric method; $\mathrm{pH}$ was 
determined with a glass electrode (organic amendment to water ratio of 1:5) and electrical conductivity with a conductivity meter in a 1:10 suspension (organic amendment to water ratio). Organic matter was quantified by the loss of weigh after ignition at $550^{\circ} \mathrm{C}$ during $16 \mathrm{~h}$. Total $\mathrm{N}$ was evaluated by Kjeldahl procedure. Total $\mathrm{P}$ was quantified after digestion with aqua regia solution (using $3.0 \mathrm{~g}$ $\mathrm{DM}+7.5 \mathrm{ml} \mathrm{HNO}_{3} 65 \%+21 \mathrm{ml} \mathrm{HCl} 37 \%$ during $2 \mathrm{~h}$ at $120^{\circ} \mathrm{C}$ [28]) and then quantified by molecular absorption spectrophotometry. Total cations such as $\mathrm{Fe}$, $\mathrm{Mn}, \mathrm{Cu}, \mathrm{Pb}, \mathrm{Cd}, \mathrm{Ni}$ and $\mathrm{Cr}$ were also extracted by the aqua regia digestion and quantified by atomic absorption spectrophotometry [28]. Total $\mathrm{K}$ and $\mathrm{Na}$ were quantified by flame emission spectrophotometry and total $\mathrm{Ca}$ and $\mathrm{Mg}$ by atomic absorption spectrophotometry. For the quantification of total $\mathrm{K}, \mathrm{Ca}, \mathrm{Mg}$ and $\mathrm{Na}$ it was used an hydrochloric acid solution $\left(\mathrm{HCl} 37 \%\right.$ diluted in $\mathrm{H}_{2} \mathrm{O}$ at a ratio of 1:1) of the ashes obtained after the ignition at $550^{\circ} \mathrm{C}$ of the organic amendments (ashes from $3 \mathrm{~g} \mathrm{DM}+75 \mathrm{ml}$ of the hydrochloric acid solution).

\subsection{Statistical Analysis}

Statistical analysis of the data was carried out with IBM SPSS statistics 26 software (https://www.ibm.com/products/spss-statistics). One-way ANOVA analyses were conducted to identify the agronomic effects of the treatments through the analysed soil properties, the crop yield (dry mater production) and the indexes of $\mathrm{N}$ and $\mathrm{P}$ use efficiency by the crop. Tukey's test was used to compare means at 0.05 probability level.

\section{Results and Discussion}

\subsection{Characterisation of the Solid Digestate and Undigested Cattle Slurry}

The chemical composition of the solid digestate (Table 2) showed that it is a product in the solid state although with a high moisture content $\left(710 \mathrm{~g} \cdot \mathrm{kg}^{-1}\right)$. This value of moisture is within the range $\left(800-570 \mathrm{~g} \cdot \mathrm{kg}^{-1}\right)$ refereed to the non-dried solid fraction of digestates (after a liquid-solid separation) by Möller [29] and Teglia et al. [30]. Consequently, the digestate had a low amount of dry matter $\left(290 \mathrm{~g} \cdot \mathrm{kg}^{-1}\right)$ which had almost $56 \%$ of organic matter. Although a large proportion of the DM of our digestate is organic its value is lower than that reported for Tambone et al. [7] which ranged between $67 \%$ - 74\% for digestates obtained from livestock slurries.

DG is referred as an alkaline product with a $\mathrm{pH}$ value in the range $7.3-9.0$ [31] [32]. Our digestate had also a $\mathrm{pH}$ within that range with a value of 7.8 and had high amounts of $\mathrm{Ca}\left(31.3 \mathrm{~kg} \cdot \mathrm{Mg}^{-1}\right.$ in the Fresh Matter-FM) and also considerable amounts of $\mathrm{Mg}\left(4.5 \mathrm{~kg} \cdot \mathrm{Mg}^{-1} \mathrm{FM}\right)$ compared with values for other digestates like 1.0 - $2.3 \mathrm{~kg} \cdot \mathrm{Mg}^{-1} \mathrm{FM}$ for $\mathrm{Ca}$ and $0.3-0.7 \mathrm{~kg} \cdot \mathrm{Mg}^{-1} \mathrm{FM}$ for $\mathrm{Mg}$ [33] [34] [35]. In relation to the $\mathrm{K}$ concentration DG showed an amount of $4.6 \mathrm{~kg} \cdot \mathrm{Mg}^{-1}$ FM within the range (1.2 - $\left.11.5 \mathrm{~kg} \cdot \mathrm{Mg}^{-1} \mathrm{FM}\right)$ reported by Möller et al. [36]. Since $\mathrm{K}$ is not a structural nutrient it occurs in dissolved forms either in the plant cells 
Table 2. Chemical composition of the anaerobic solid digestate (DG) and the undigested cattle slurry (CS) used in the pot experiment.

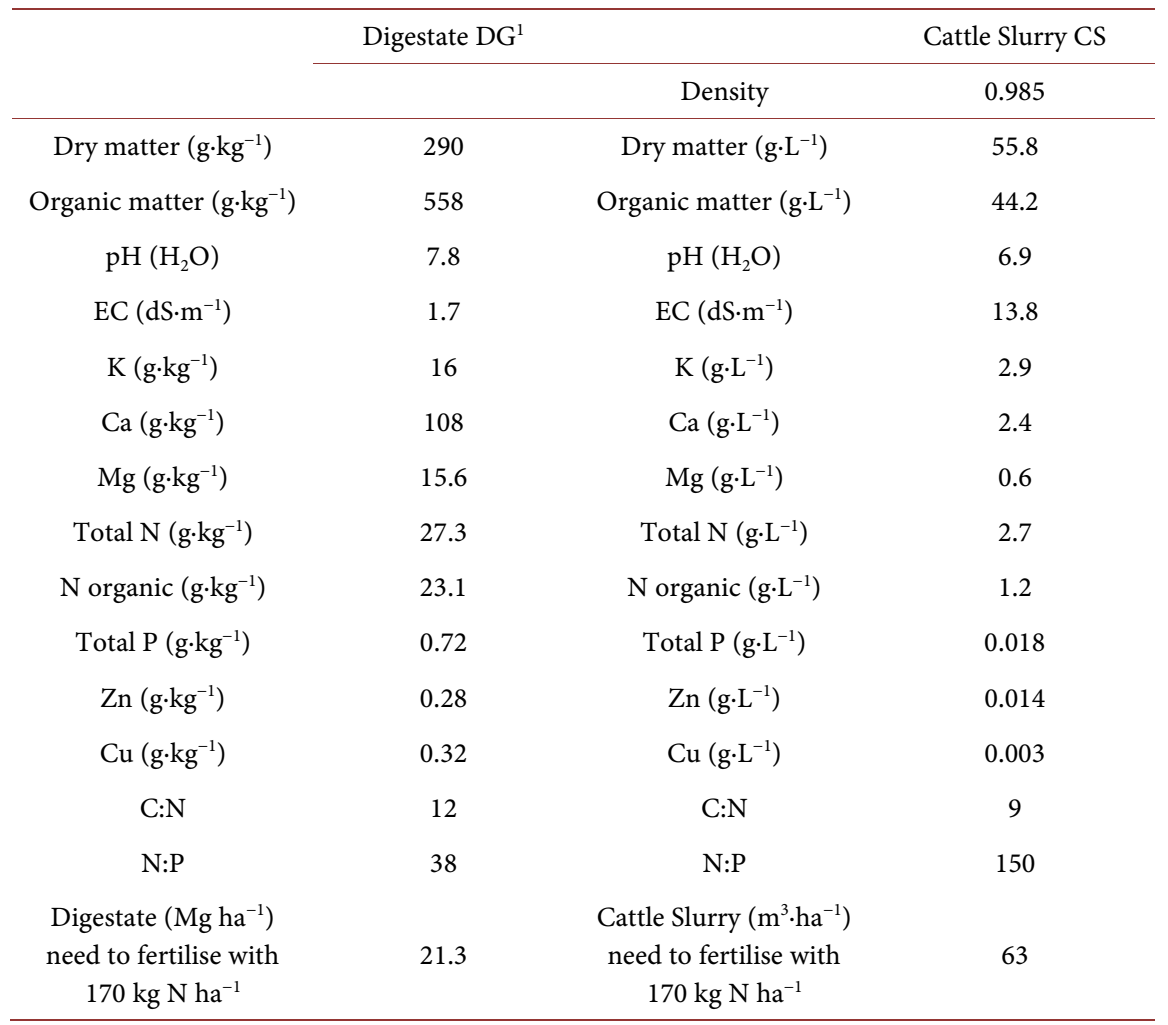

${ }^{1}$ All the parameters analysed in the digestate are expressed on a dry matter basis excluding density, $\mathrm{pH}$ and CE.

and in the digestates therefore, the liquid phase of the digestates is characterised by higher $\mathrm{K}$ contents than the solid phase [12]. DG had low values of $\mathrm{Na}(0.9$ $\mathrm{kg} \cdot \mathrm{Mg}^{-1} \mathrm{FM}$ ) and also of electrical conductivity (EC of $1.7 \mathrm{dS} \cdot \mathrm{m}^{-1}$ ). EC of digestate was within the normal range considering that $3 \mathrm{dS} \cdot \mathrm{m}^{-1}$ is the threshold value for irrigation water quality to prevent soil salinity [37]. Although most of the total $\mathrm{P}$ is allocated to the solid phase our DG has a low amount of $\mathrm{P}\left(0.72 \mathrm{~g} \cdot \mathrm{kg}^{-1}\right.$ DM) compared with the values referred by other authors 2 - $35 \mathrm{~g} \cdot \mathrm{kg}^{-1} \mathrm{DM}$ [6] [34] [36] [38]. In general, the liquid phase of the digestates had a higher proportion of mineral N than the solid fraction [36]. Despite our DG has been pressed after digestion it had a total $\mathrm{N}$ content of $27.3 \mathrm{~g} \cdot \mathrm{kg}^{-1} \mathrm{DM}$ within the values indicated by Tegila et al. [30] for digestates obtained from animal slurries without phase separation but lower than the values (total $\mathrm{N}$ of $53-151 \mathrm{~g} \cdot \mathrm{kg}^{-1} \mathrm{DM}$ ) reported by Tambone et al. [7]. Nevertheless, $85 \%$ of the total N in DG was in organic forms, and this fact together with a $\mathrm{C}: \mathrm{N}$ ratio of 12 suggests also that the rate of $\mathrm{N}$ mineralisation of DG may be slow and may not release $\mathrm{N}$ at a rate similar to that of crop needs for the time of a single crop cycle. In turn, CS is a fluid material which showed a low amount of dry matter $\left(55.8 \mathrm{~g} \cdot \mathrm{L}^{-1}\right)$ and of organic matter $\left(44.2 \mathrm{~g} \cdot \mathrm{L}^{-1}\right)$. It had a $\mathrm{pH}$ in the neutral range ( $\mathrm{pH}$ of 6.9) lower than DG. Pötsch et al. [38] referred an increase of about 0.8 units in the $\mathrm{pH}$ value of digestates compared with undigested livestock slurries. That increase in $\mathrm{pH}$ value 
of DG affects the equilibrium between the inorganic- $\mathrm{N}$ forms of $\mathrm{NH}_{3} / \mathrm{NH}_{4}$ and favours the increase of $\mathrm{N}$ losses by volatilisation of $\mathrm{N}-\mathrm{NH}_{3}$ in DG. CS had lower amounts of $\mathrm{Ca}$ and $\mathrm{Mg}$ (2.4 and $0.6 \mathrm{~g} \cdot \mathrm{L}^{-1}$ respectively) and higher amounts of $\mathrm{K}$ and $\mathrm{Na}\left(3.0\right.$ and $\left.1.1 \mathrm{~g} \cdot \mathrm{L}^{-1}\right)$ than DG. CS had a high level of electrical conductivity $\left(13.8 \mathrm{dS} \cdot \mathrm{m}^{-1}\right)$ which limits the annual volume to be used in agricultural soils in order to prevent soil salinity. CS had a low content of P $\left(0.018 \mathrm{~g} \cdot \mathrm{L}^{-1}\right)$ and a considerable content of total $\mathrm{N}\left(2.7 \mathrm{~g} \cdot \mathrm{L}^{-1}\right)$. It had $56 \%$ of total $\mathrm{N}$ in organic forms and a lower C:N ratio ( $\mathrm{C}: \mathrm{N}$ of 9 ) which suggests that $\mathrm{CS}$ can have a faster mineralisation rate than DG and thus, in principle, could provide $\mathrm{N}$ to the crop needs soon after its incorporation into the soil.

The levels of other nutrients in DG and CS such as $\mathrm{Cu}, \mathrm{Zn} \mathrm{Fe}, \mathrm{Mn}$ and $\mathrm{Ni}$ and non-nutrients such as $\mathrm{Cd}, \mathrm{Cr}$ and $\mathrm{Pb}$ (data not shown) were below the threshold levels compared with those established for agricultural use of composts by the Portuguese legislation [39]. Concerning the microbiological analysis, the digestate was free of microorganisms of faecal origin such as Escherichia coli which had $6.3 \times 10^{2} \mathrm{CFU} \cdot \mathrm{g}^{-1}$ and Salmonella spp. which was not detected. These values are also in accordance with the above-mentioned legislation [39].

The standards of some European countries [39] [40] [41] specify for products to be considered as soil amendments (those that have a beneficial effect on soil OM) that their OM content should be between $20 \%-90 \%$ in a DM basis and should have a dry matter content higher than $30 \%-50 \%$ [39] [42]. In relation to the $\mathrm{C} / \mathrm{N}$ ratio it should be higher than 8 [42]. So, overall the digestate meet the standards except for the dry matter content slightly below the minimum threshold level (29\%).

\subsection{Assessment of the Fertilising Properties}

\section{Soil fertility}

While the digestate and the undigested cattle slurry presented contrasting OM contents, the content of soil organic matter after the experiment (Figure 1(a)) had low variations and did not change significantly $(P>0.05)$ between the treatments. The soil OM ranged between $28.3 \mathrm{~g} \cdot \mathrm{kg}^{-1}$ in NoPi_DG and $33.2 \mathrm{~g} \cdot \mathrm{kg}^{-1}$ in NoNi_CS. Indeed, although the digestate had $558 \mathrm{~g} \cdot \mathrm{kg}^{-1}$ of OM on a dry matter basis it has only $162 \mathrm{~g} \cdot \mathrm{kg}^{-1}$ of OM in the fresh matter. So, the amount of OM incorporated into soil in the No_DG treatment was only $3.5 \mathrm{Mg} \mathrm{ha}^{-1}$ and in the No_CS treatment was $2.8 \mathrm{Mg} \mathrm{ha}^{-1}$. The relatively low values of the C:N ratios of the digestate and the cattle slurry (12 and 9 respectively) together with the relatively low amount of OM incorporate into soil didn't favour an increase of the $\mathrm{OM}$ of the soil through a single application. Teglia et al. [30] referred that values higher than 40 for the $\mathrm{OM} / \mathrm{N}_{\text {org }}$ ratio implies a low organic nitrogen content of the digestates and thus their beneficial effects as soil amendments could be limited due to a nitrogen immobilisation after soil incorporation. The $\mathrm{OM} / \mathrm{N}_{\text {org }}$ of our DG is 24 , it has a $\mathrm{C} / \mathrm{N}$ ratio of 12 higher than 8 considered the threshold level by the French criteria for soil amendments [42] and its $\mathrm{C} / \mathrm{N}$ ratio is also in the range of $10-20$ a criterion for the stability and maturity of soil amendments 
[43] [44]. So, the lack of response to increase soil organic matter will be due mainly to the low amount of digestate incorporated into soil as a consequence of its high moisture content $\left(710 \mathrm{~g} \cdot \mathrm{kg}^{-1}\right)$.

Concerning the EC values after the experiment the fertilisation with $\mathrm{N}$ and $\mathrm{P}$ leads in all the treatments to a significantly increase $(P<0.001)$ in the soil EC (Figure 1(b)) compared with the control treatment and with treatments without $\mathrm{P}$ application. However, all treatments had very low EC values (0.04 in N0P0 and $0.1 \mathrm{dS} \cdot \mathrm{m}^{-1}$ in NoPi_DG) far from $0.4 \mathrm{dS} \cdot \mathrm{m}^{-1}$ considered the soil threshold level to avoid saline effects for the crops. Although the fertilisation led to significant variations in the soil $\mathrm{pH}$ (Figure $1(\mathrm{c}), \mathrm{P}<0.001$ ) the soil remains acidic with values ranged between 5.1 (NiPi) and 5.6 (No_DG and No_CS). The control treatment showed a $\mathrm{pH}$ value of 5.4. The significantly higher $\mathrm{pH}$ in treatments with the application of digestate or cattle slurry as the only fertiliser suggests that the content of basic cations (namely $\mathrm{Ca}$ and $\mathrm{Mg}$ ) of these organic amendments should have a significant effect on the decrease of soil acidity and could promote better conditions for plant nutrition in the acidic soils. It was observed also that the sum of the soil exchangeable bases (Figure 2) increased significantly $(\mathrm{P}<$ 0.001 ), namely the exchangeable $\mathrm{Ca}$, in the treatments with the digestate application (No_DG).

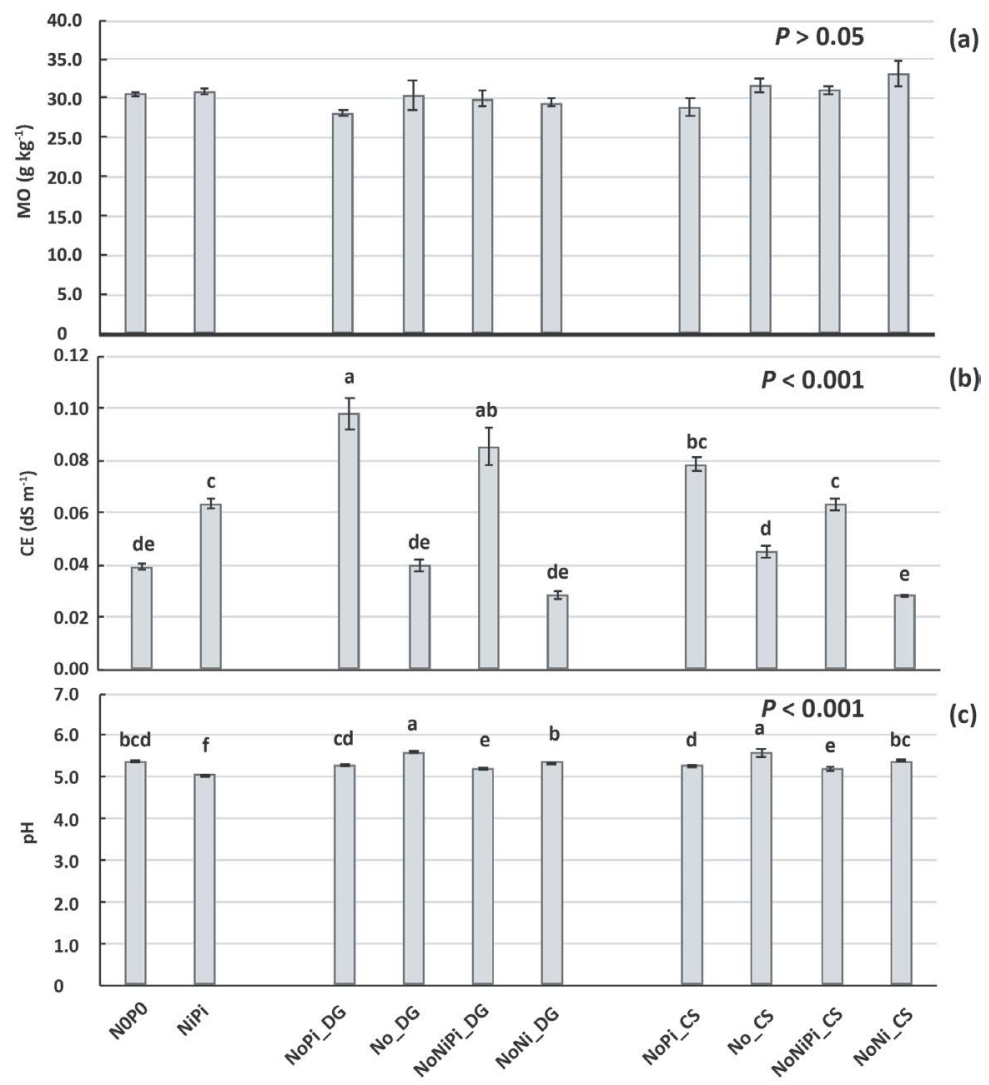

Figure 1. Some soil properties after the pot experiment (a) MO $\left(\mathrm{g} \cdot \mathrm{kg}^{-1}\right.$, mean $\left.\pm \mathrm{SE}\right)$, (b) $\mathrm{EC}\left(\mathrm{dS} \cdot \mathrm{m}^{-1}\right.$, mean $\left.\pm \mathrm{SE}\right)$ and $\left.\mathrm{c}\right) \mathrm{pH}($ mean $\pm \mathrm{SE})$ as a function of the fertiliser treatments. Different letters over the bars indicate for each property significant differences by the Tukey test at the $\mathrm{P}<0.05$ level by the Tukey test. 


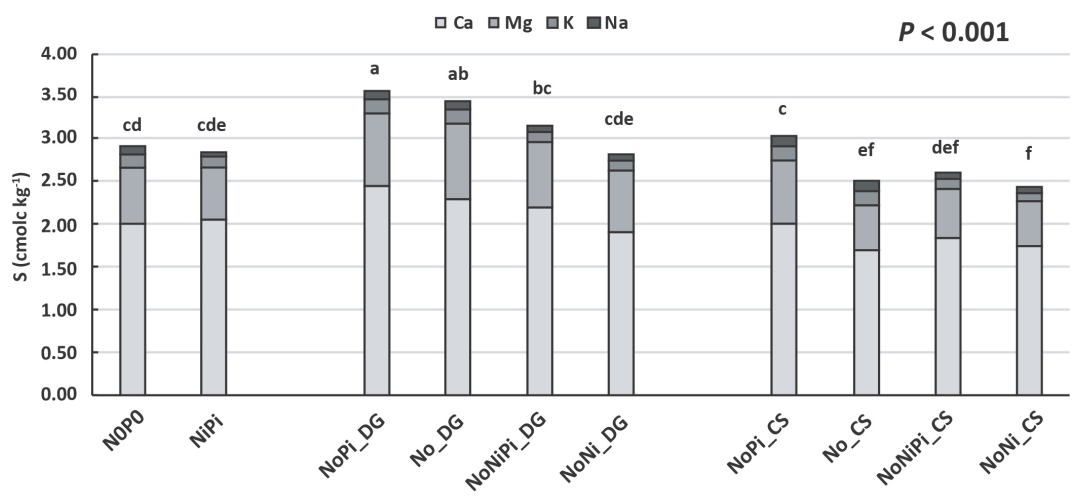

Figure 2. Sum of the soil exchangeable bases ( $\mathrm{Ca}, \mathrm{Mg}, \mathrm{K}, \mathrm{Na}$ expressed in $\mathrm{cmol}_{\mathrm{c}} \cdot \mathrm{kg}^{-1}$, mean \pm SE) as a function of the fertiliser treatments. Different letters over the bars indicate significant differences by the Tukey test at the $\mathrm{P}<0.05$ level.

Although the digestate had considerable amounts of $\mathrm{Ca}$ and $\mathrm{Mg}$ a single application of digestate was not enough to increase the soil fertility class of the exchangeable bases which remained at low levels $(\mathrm{Ca} \cong 2.5, \mathrm{Mg} \cong 0.86, \mathrm{~K} \cong 0.16$ and $\mathrm{Na} \cong 0.1 \mathrm{cmol}_{c} \cdot \mathrm{kg}^{-1}$ ). The treatments fertilised with superphosphate (Figure $3(\mathrm{a}))$ showed a significantly increase $(\mathrm{P}<0.001)$ compared with the control treatment in soil available $\mathrm{P}$, measured by the Olsen method.

However, this increase is more evident in the treatments fertilised with superphosphate together with digestate. The treatment NoPi_DG has the highest Olsen-P level $\left(26 \mathrm{mg} \cdot \mathrm{kg}^{-1}\right)$ and the NoNi_CS treatment had the lowest value (10 $\left.\mathrm{mg} \cdot \mathrm{kg}^{-1}\right)$. In addition, DG showed also a significantly increase $(\mathrm{P}<0.001)$ in the $\mathrm{P}$ recovery (87\% and 64\% in NoPi_DG and NoNiPi_DG, respectively) by the Olsen method (Equation (3) and Figure 3(b)) compared with the NiPi treatment (50\%) and even with CS for similar treatments (54\% and 33\%). In other work with the same type of soil Horta [45] observed a reduction in soil sorption capacity after a compost addition to soil accompanied by an increase in soil available P. This P behaviour was also observed in other works [46] [47] [48] and could be explain by the competition with the phosphate anion for adsorption sites by the organic anions of the organic material (the digestate in our experiment) produced during its decomposition into the soil.

\section{Ryegrass yield}

Overall the fertilisation significantly increased $(\mathrm{P}<0.001)$ the ryegrass yields irrespective of the nutrients source (Table 3).

The control treatment ( $\mathrm{NOP} 0)$ showed the lowest cumulative ryegrass yield (10.03 $\mathrm{g} \mathrm{DM} \mathrm{pot}^{-1}$ ) and the highest yield was obtained in the treatments with only mineral fertilisation NiPi (33.68 $\mathrm{g} \mathrm{DM} \mathrm{pot}^{-1}$ ) or in DG and CS treatments but with half of the $\mathrm{N}$ fertilisation from those organic sources and the other half

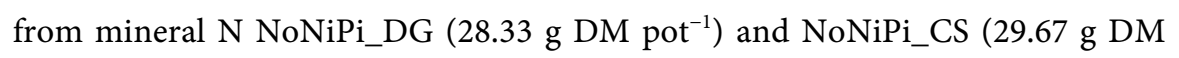
pot $^{-1}$ ) but always with mineral P fertilisation. When the total amount of $\mathrm{N}$ (170 $\left.\mathrm{kg} \cdot \mathrm{ha}^{-1}\right)$ was applied only by DG or CS the yields decreased significantly $(\mathrm{P}<$ 0.001 ) in relation to treatments with any $\mathrm{N}$ mineral fertilisation. 

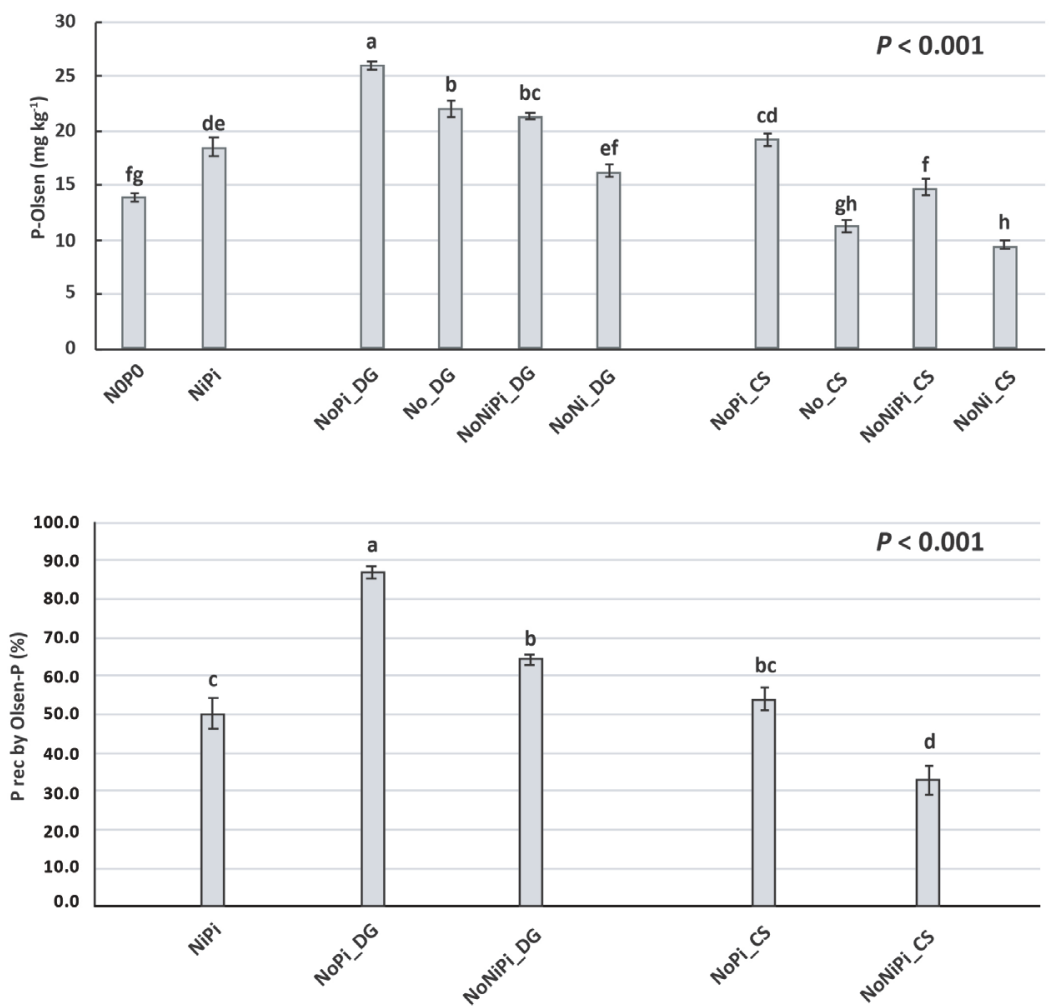

(b)

Figure 3. (a) Soil Olsen $\mathrm{P}$ after the experiment ( $\mathrm{mg} \cdot \mathrm{kg}^{-1}$, mean $\pm \mathrm{SE}$ ) and (b) P recovery by the Olsen method (\%) as a function of the fertiliser treatments. Different letters over the bars indicate for each property significant differences by the Tukey test at the $\mathrm{P}<0.05$ level.

Table 3. Biomass production (mean of dry matter \pm SE) in the first $\left(1^{\text {st }}\right)$, second $\left(2^{\text {nd }}\right)$ and third $\left(3^{\text {rd }}\right)$ cuts and total dry matter $(D M)$ yield of ryegrass as a function of the fertiliser treatments.

\begin{tabular}{cccccccccc}
\hline Treatment & $\begin{array}{c}1^{\text {st }} \text { cut } \\
\text { g DM pot }^{-1}\end{array}$ & $\begin{array}{c}2^{\text {nd }} \text { cut } \\
\text { g DM pot }^{-1}\end{array}$ & $\begin{array}{c}3^{\text {rd }} \text { cut } \\
\text { g DM pot }^{-1}\end{array}$ & \multicolumn{2}{c}{$\begin{array}{c}\text { Total } \\
\text { g DM pot }^{-1}\end{array}$} \\
\hline N0P0 & $2.85 \pm 0.20$ & e & $4.39 \pm 0.62$ & e & $2.79 \pm 0.32$ & c & $10.03 \pm 0.90$ & f \\
NiPi & $5.57 \pm 0.30$ & cd & $14.61 \pm 0.18$ & a & $13.50 \pm 0.66$ & a & $33.68 \pm 0.53$ & a \\
NoPi_DG & $8.13 \pm 0.52$ & ab & $6.21 \pm 0.41$ & de & $3.61 \pm 0.14$ & c & $17.94 \pm 0.87$ & de \\
No_DG & $7.77 \pm 0.10$ & abc & $5.84 \pm 0.41$ & de & $3.76 \pm 0.16$ & b & $17.37 \pm 0.48$ & de \\
NoNiPi_DG & $6.98 \pm 0.31$ & bc & $10.99 \pm 0.09$ & bc & $10.37 \pm 0.45$ & b & $28.33 \pm 0.32$ & ab \\
NoNi_DG & $6.18 \pm 0.87$ & bcd & $10.59 \pm 0.91$ & bc & $9.11 \pm 0.43$ & b & $25.88 \pm 2.15$ & bc \\
NoPi_CS & $9.63 \pm 0.42$ & a & $8.64 \pm 0.26$ & cd & $3.91 \pm 0.29$ & c & $22.18 \pm 0.47$ & cd \\
No_CS & $5.53 \pm 0.34$ & cd & $6.88 \pm 0.42$ & de & $3.65 \pm 0.42$ & c & $16.06 \pm 0.99$ & ef \\
NoNiPi_CS & $7.34 \pm 0.65$ & bc & $11.82 \pm 1.12$ & ab & $10.51 \pm 0.63$ & b & $29.67 \pm 2.29$ & ab \\
NoNi_CS & $4.03 \pm 0.62$ & de & $11.02 \pm 0.51$ & bc & $9.32 \pm 0.28$ & b & $24.37 \pm 1.28$ & bc \\
P & $<0.001$ & & $<0.001$ & & $<0.001$ & & $<0.001$ &
\end{tabular}

Different letters in the columns indicate for each cut and for the cumulative dry matter yield significant differences by the Tukey test at the $\mathrm{P}<0.05$ level. 
Concerning the comparison between DG treatments with and without P fertilisation the yields didn't change significantly but for CS the NoPi_Cs and No_Cs were significantly different. These results suggest that the main shortcoming for ryegrass nutrition with DG should be the $\mathrm{N}$ availability but for CS should be not only $\mathrm{N}$ but also $\mathrm{P}$ availability. In addition, the ryegrass yields between the three cuts showed a great variability (Table 3 ) caused, in principle, by changes in the $\mathrm{N}$ availability of DG and CS throughout the crop cycle. Thus, in the first cut the DG and CS treatments with NoPi showed higher yields than the NiPi treatment $(\mathrm{P}<0.001)$. In turn in the second cut the NiPi treatment showed the highest ryegrass yield $(\mathrm{P}<0.001)$ and only NoNiPi_CS had a similar yield. Finally, at the end of the crop cycle the highest yield was obtained only in the $\mathrm{NiPi}$ treatment. These results suggest that throughout the crop cycle the availability of N from DG or CS changed. Soon after DG or CS application in treatments with only No application the fertilising effect is better than NiPi in principle because of a higher $\mathrm{N}$ availability than $\mathrm{NiPi}$ (in NiPi treatment the Ni application rate at sowing was only $85 \mathrm{~kg} \cdot \mathrm{ha}^{-1}$ ).

Indeed, in the DG and CS treatments with NoNi there were no significant differences from NiPi indicating a similar $\mathrm{N}$ availability. But in the second and third cut the availability of $\mathrm{N}$ form DG or CS was not enough for the ryegrass needs. In the second cut the lower N availability of DG compared with CS could be explained by a slower mineralisation rate and even a partial $\mathrm{N}$ immobilisation of the inorganic $\mathrm{N}$ applied as topdressing after the first cut. Indeed, other authors [49] [50] observed also a partial $\mathrm{N}$ immobilisation after the addition to soil of a solid digestate from cattle slurry and justify it by an increase in the soil microbial activity caused by the addition of easily degradable organic matter from DG.

\section{Nitrogen and phosphorus use efficiency indexes}

Concerning the efficiency indexes, we can observe that the $\mathrm{N}$ uptake (Figure 4(a)) was higher $(\mathrm{P}<0.001)$ in the NiPi treatment but without significant differences from the DG treatments NoNi and of NoPi_CS and NONiPi_CS. Although in the first cut the uptake of $\mathrm{N}$ in No_DG treatments were similar to $\mathrm{NiPi}$ at the end of the crop cycle the total $\mathrm{N}$ uptake was similar to the control treatment. This behaviour confirms the decrease in $\mathrm{N}$ availability from DG in the second and third cuts. Regarding P uptake (Figure 4(b)) it was higher in DG treatments (except in No_DG) and in CS treatments with Pi fertilisation (NoPi_CS and NoNiPi_CS) in comparison with NiPi. This higher P uptake in treatments fertilised with organic amendments compared with only mineral fertilisation may be due to an improvement in soil $\mathrm{P}$ availability (Olsen $\mathrm{P}$ and $\mathrm{P}$ recovery increased in DG treatments, Figure 3) caused by the role of the organic matter on the decrease of soil P sorption of the applied P and/or an increase in soil P desorption as explained above. However, the behaviour of CS in improving soil $\mathrm{P}$ availability could be lower than that of DG as observed by the deeper decrease in $\mathrm{P}$ uptake in treatments without $\mathrm{P}$ application in CS compared with DG. Liedl et 
al. [15] observed an increase in soil available $\mathrm{P}$ with solid digestate application over a four-year field experiment. Nevertheless, their digestate had a higher amount of $\mathrm{P}$ than that we used in our work, in fact we only applied $4 \mathrm{~kg} \mathrm{P} \mathrm{ha}^{-1}$ from DG and $1 \mathrm{~kg} \mathrm{P} \mathrm{ha}^{-1}$ from CS in the NoPi treatments. Such low $\mathrm{P}$ addition from the organic amendments is not enough to justify by itself the observed increases in $\mathrm{P}$ uptake.

The other indexes like the $\mathrm{N}$ agronomic efficiency and the $\mathrm{N}$ apparent recovery (Equations 1 and 2, Figure 5) showed significant differences between the treatments $(\mathrm{P}<0.001)$ with similar behaviour between them as referred above for $\mathrm{N}$ uptake. In relation to these indexes the $\mathrm{N}$ apparent recovery is higher in $\mathrm{NiPi}$, NoNiPi and NoNi with DG and CS while the $\mathrm{N}$ agronomic efficiency was higher in NiPi and only in NoNiPi treatments highlighting the need of complementary Ni and Pi fertilisation to obtain a $\mathrm{N}$ and $\mathrm{P}$ efficiency use similar to NiPi treatment. Möller and Müller [12] referred that DG applied directly with incorporation into soil immediately after field spreading provide plant available $\mathrm{NH}_{4}$ content plus a small part of the No fraction $(10 \%-20 \%)$. In our work DG had $85 \%$ of total $\mathrm{N}$ in organic forms so, the amount of available $\mathrm{N}$ seems to be enough in the short-term at least for $50 \%$ of all the ryegrass needs in $\mathrm{N}$.

At the end of the crop cycle the $\mathrm{P}$ apparent recovery ranged between $27 \%$ in $\mathrm{NiPi}$ and 43\% in NoNiPi_DG (P < 0.05, Equation (1), Figure 6(b)) with no significant differences between the other treatments. The $\mathrm{P}$ agronomic efficiency was significantly higher $(\mathrm{P}<0.01)$ in NiPi, NoNiPi_DG and NoNiPi_CS treatments (Equation (2), Figure 6(a)). The results of the agronomic indexes seem to

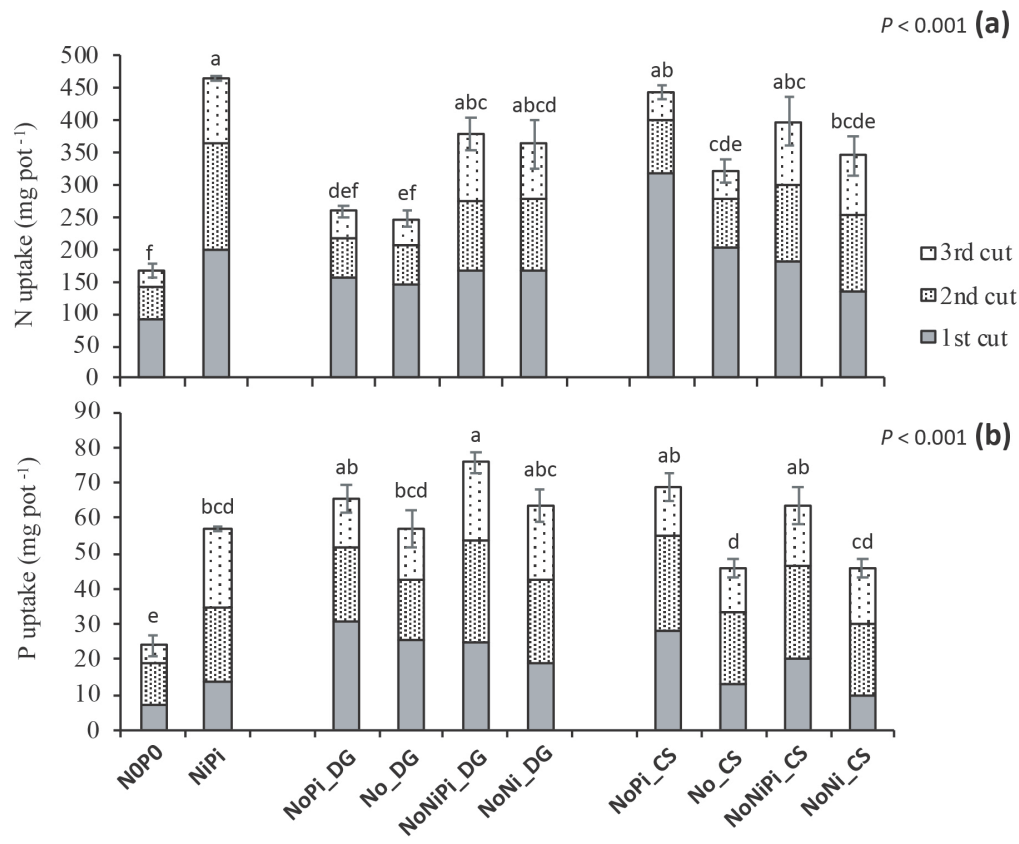

Figure 4. (a) Nitrogen uptake and (b) phosphorus uptake, in the first $\left(1^{\text {st }}\right)$, second $\left(2^{\text {nd }}\right)$ and third $\left(3^{\text {rd }}\right)$ cuts and by total biomass production (mean $\pm \mathrm{SE}$ ) of ryegrass as a function of the fertiliser treatments. Different letters above the columns indicate significant differences by the Tukey test at the $\mathrm{P}<0.05$ level. 


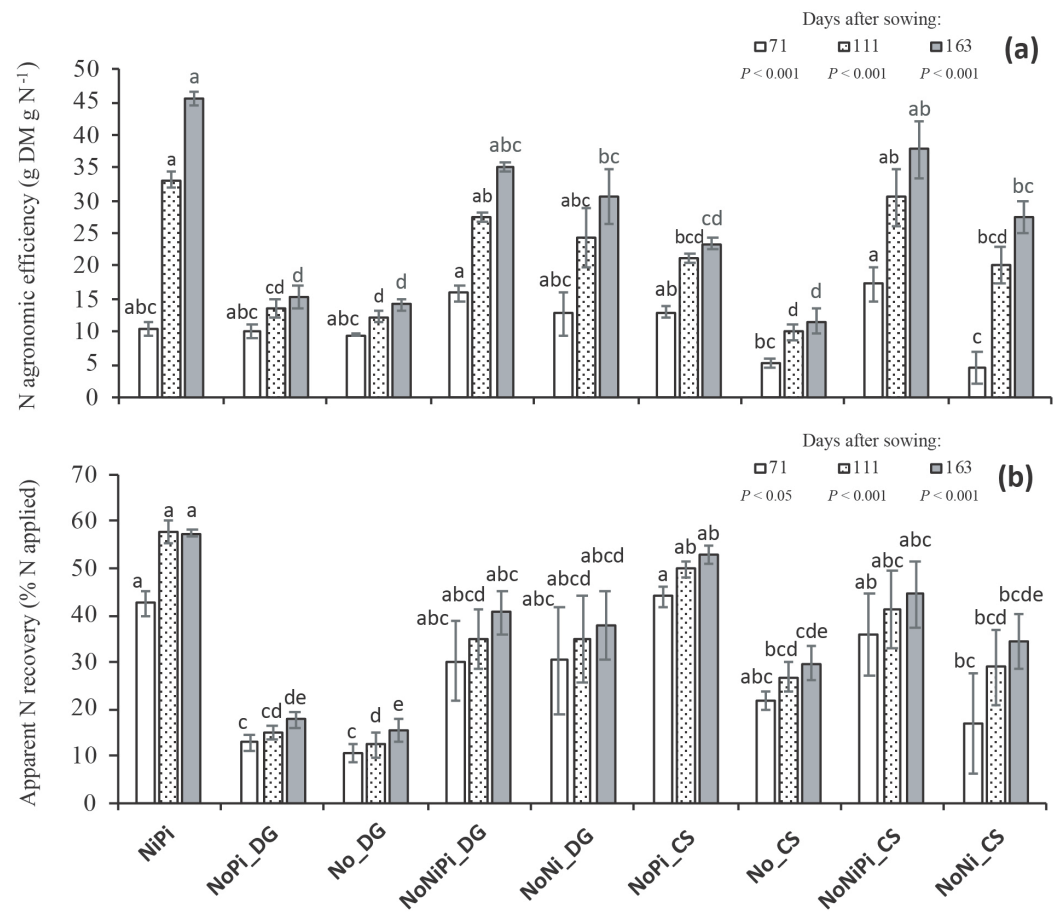

Figure 5. (a) $\mathrm{N}$ agronomic efficiency evolution (mean $\pm \mathrm{SE}$ ) and (b) $\mathrm{N}$ apparent recovery evolution (mean $\pm \mathrm{SE}$ ) throughout the crop cycle of ryegrass $(71,111$ and 163 days after sowing) as a function of the fertiliser treatments. Different letters above the columns indicate for each date significant differences between the treatments by the Tukey test at the $\mathrm{P}<0.05$ level.

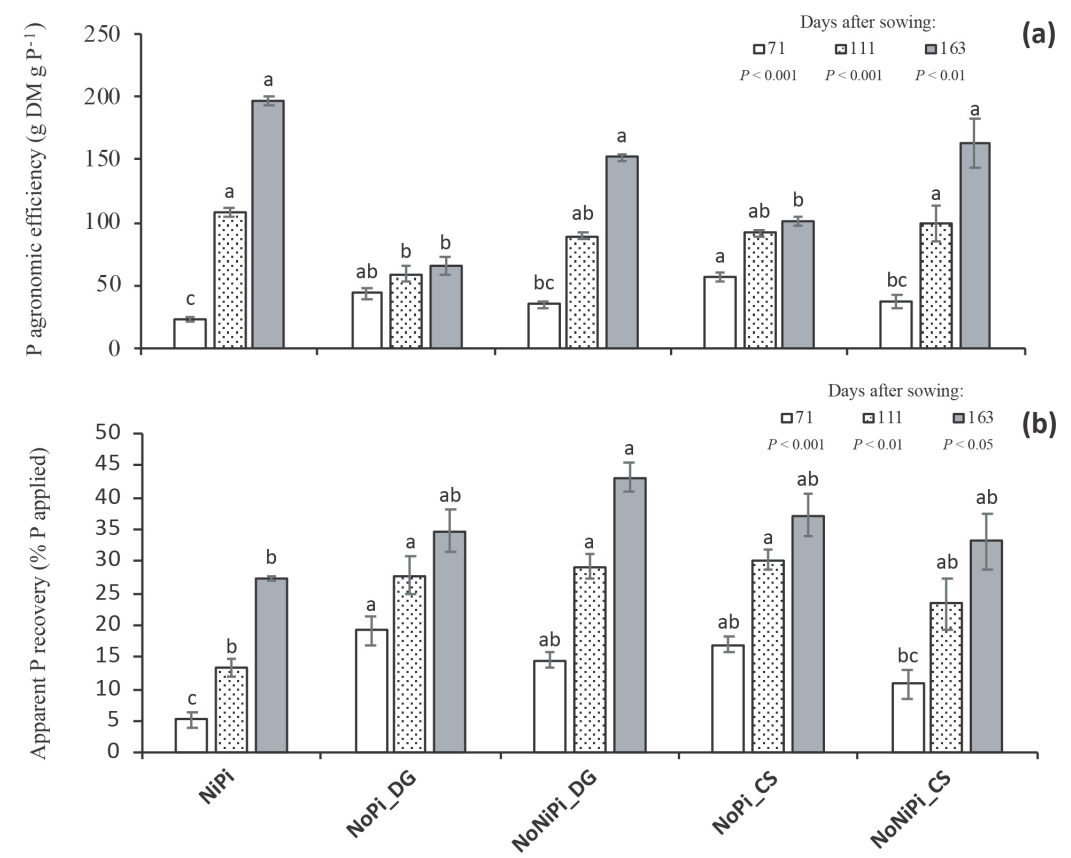

Figure 6. (a) $\mathrm{P}$ agronomic efficiency evolution (mean $\pm \mathrm{SE}$ ) and (b) $\mathrm{P}$ apparent recovery evolution (mean $\pm \mathrm{SE}$ ) throughout the crop cycle of ryegrass $(71,111$ and 163 days after sowing) as a function of the fertiliser treatments. Different letters above the columns indicate for each date significant differences between the treatments by the Tukey test at the $\mathrm{P}<0.05$ level. 
confirm that there is a shortcoming on $\mathrm{N}$ uptake by the ryegrass in the treatments with only No fertilisation (No_DG and No_CS) caused by a decrease in N availability, in the short-term, which caused also a decrease of the $\mathrm{P}$ uptake and an overall decrease of the agronomic indexes.

\section{Conclusions}

The solid digestate used in this work didn't change the organic matter content of the soil. In fact, the use of digestate as soil amendment was limited by both its high amount of moisture together with the regulated amount of $\mathrm{N}$ allowed for soil application from organic sources $\left(170 \mathrm{~kg} \mathrm{~N} \mathrm{ha}^{-1}\right)$ which led to a low amount of OM incorporation into soil. Regarding the undigested cattle slurry since it was a liquid effluent with a very low amount of OM it had, as expected, no effect as soil improver.

Compared with the undigested cattle slurry and with the mineral fertilisation the solid digestate provided an increase in the soil $\mathrm{pH}$ and in the sum of the exchangeable bases namely in exchangeable Ca. The fertilisation with solid digestate together with SSP significantly increased the content of soil available P.

Though with forms of organic $\mathrm{N}$ of slower mineralisation the anaerobic solid digestate showed similar crop performance than undigested cattle slurry. Both of these organic amendments allowed a reduction in the total amount of $\mathrm{N}$ mineral fertiliser used by replacing the mineral $\mathrm{N}$ fertilisation at sowing. Digestate allowed for higher soil $\mathrm{P}$ availability than undigested cattle slurry, so the fertilisation of ryegrass with solid digestate needs less mineral $\mathrm{P}$ addition to achieve similar yields. In addition to provide biogas, anaerobic solid digestate has similar or even better fertilising properties than undigested cattle slurry for forage production in acidic soils.

\section{Acknowledgements}

This research was funded by the project INTERREG 0340_SYMBIOSIS_3_E and funding by the Portuguese National Funds through FCT-Portuguese Foundation for Science and Technology under project UIDB/00681/2020.

The authors gratefully acknowledge support with the laboratory analysis and with the experiment maintenance to Marta Batista, Isabel Dias and Abel Veloso.

\section{Conflicts of Interest}

The authors declare no conflicts of interest regarding the publication of this paper.

\section{References}

[1] Tani, M., Sakamoto, N., Kishimoto, T. and Umetsu, K. (2006) Utilization of Anaerobically Digestate Slurry Combined with Other Waste Following Application to Agricultural Land. International Congress. Series, 1293, 331-334. https://doi.org/10.1016/j.ics.2006.03.013

[2] Tambone, F., Genevini, P., D’Imporzano, G. and Adani, F. (2009) Assessing Amend- 
ment Properties of Digestate by Studying the Organic Matter Composition and the Degree of Biological Stability during the Anaerobic Digestion of the Organic Fraction of MSW. Bioresource Technology, 100, 3140-3142.

https://doi.org/10.1016/j.biortech.2009.02.012

[3] International Energy Agency (2020) Outlook for Biogas and Biomethane: Prospects for Organic Growth. World Energy Outlook Special Report.

https://www.iea.org/reports/outlook-for-biogas-and-biomethane-prospects-for-org anic-growth/annex

[4] Monteiro, E., Mantha, V. and Rouboa, A. (2011) Prospective Application of Farm Cattle Manure for Bioenergy Production in Portugal. Renewable Energy, 36, 627-631. https://doi.org/10.1016/j.renene.2010.08.035

[5] Holm-Nielsen, J.B., Al Seadi, T. and Oleskowicz-Popiel, P. (2009) The Future of Anaerobic Digestion and Biogas Utilization. Bioresource Technology, 100, 5478-5484. https://doi.org/10.1016/j.biortech.2008.12.046

[6] Teglia, C., Tremier, A. and Martel, J.-L. (2011) Characterization of Solid Digestates: Part I, Review of Existing Indicators to Assess Solid Digestates Agricultural Use. Waste and Biomass Valorization, 2, 43-58. https://doi.org/10.1007/s12649-010-9051-5

[7] Tambone, F., Scaglia, B., D’Imporzano, G., Schievano, A., Orzi, V., Salati, S. and Adani, F. (2010) Assessing Amendment and Fertilizing Properties of Digestates from Anaerobic Digestion through a Comparative Study with Digested Sludge and Compost. Chemosphere, 81, 577-583. https://doi.org/10.1016/j.chemosphere.2010.08.034

[8] Lorenz, K., Lal, R., Preston, C.M. and Nierop, K.G.J. (2007) Strengthening the Soil Organic Carbon Pool by Increasing Contributions from Recalcitrant Aliphatic Bio(macro)molecules. Geoderma, 142, 1-10. https://doi.org/10.1016/j.geoderma.2007.07.013

[9] Riva, C., Orzi, V., Carozzi, M., Acutis., Boccasile, G., Lonati S., Tambone, F., D'Imporzano, G. and Adani, F. (2016) Short-Term Experiments in Using Digestate Products as Substitutes for Mineral (N) Fertilizer: Agronomic Performance, Odours, and Ammonia Emission Impacts. Science of Total Environment, 547, 206-214. https://doi.org/10.1016/j.scitotenv.2015.12.156

[10] Nkoa, R. (2014) Agricultural Benefits and Environmental Risks of Soil Fertilization with Anaerobic Digestates: A Review. Agronomy for Sustainable Development, 34, 473-492. https://doi.org/10.1007/s13593-013-0196-Z

[11] Albuquerque, J.A., de la Fuente, C., Campoy, M., Carrasco, L., Nájera, I., Baixauli, C., Caravaca, F., Roldán, A., Cegarra, J. and Bernal, M.P. (2012) Agricultural Use of Digestate for Horticultural Crop Production and Improvement of Soil Properties. European Journal of Agronomy, 43, 119-128. https://doi.org/10.1016/j.eja.2012.06.001

[12] Möller, K. and Müller, T. (2012) Effects of Anaerobic Digestion on Digestate Nutrient Availability and Crop Growth: A Review. Engineering in Life Sciences, 12, 242-257. https://doi.org/10.1002/elsc.201100085

[13] Garfí, M., Gelman, P., Comas, J., Carrasco, W. and Ferrer, I. (2011) Agricultural Reuse of Digestate from Low-Cost Tubular Digesters in Rural Andean Communities. Waste Management, 31, 2584-2589. https://doi.org/10.1016/j.wasman.2011.08.007

[14] Thomas, C.L., Acquah, G.E., Whitmore, A.P., McGrath, S.P. and Haefele, S.M. (2019) The Effect of Different Organic Fertilizers on Yield and Soil and Crop Nu- 
trient Concentrations. Agronomy, 9, 776. https://doi.org/10.3390/agronomy9120776

[15] Liedl, B.E., Bombardiere, J. and Chatfield, J.M. (2006) Fertilizer Potential of Liquid and Solid Effluent from Thermophilic Anaerobic Digestion of Poultry Waste. Water Science and Technology, 53, 69-79. https://doi.org/10.2166/wst.2006.237

[16] Müller, C., Laughlin, R.J., Christie, P. and Watson, J.C. (2011) Effects of Repeated Fertilizer and Cattle Slurry Applications over 38 Years on N Dynamics in a Temperate Grassland Soil. Soil Biology and Biochemistry, 43, 1362-1371. https://doi.org/10.1016/j.soilbio.2011.03.014

[17] Møller, H.B., Lund, I. and Sommer, S.G. (2000) Solid-Liquid Separation of Livestock Slurry: Efficiency and Cost. Bioresource Technology, 74, 223-229. https://doi.org/10.1016/S0960-8524(00)00016-X

[18] Nyord, T. (2009) Field Application Methods for the Liquid Fraction of Separated Animal Slurry in Growing Cereal Crops. In: Ashley, K., Mavinic, D. and Koch, F., Eds., International Conference on Nutrient Recovery from Wastewater Streams, IWA Publishing, London, 317-326.

[19] IUSS Working Group WRB (2015) World Reference Base for Soil Resources 2014, Update 2015 International Soil Classification System for Naming Soils and Creating Legends for Soil Maps. World Soil Resources Reports No. 106, FAO, Rome.

[20] Chapman, H.D. (1965) Cation-Exchange Capacity. In: Norman, A.G., Ed., Methods of Soil Analysis. Part 2 Chemical and Microbiological Properties, American Society of Agronomy, Madison, 891-901. https://doi.org/10.2134/agronmonogr9.2.c6

[21] Despacho no 1230 (2018) Diário da República, 2a Série, № 25-5 fevereiro de 2018.

[22] Syers, J.K., Johnston, A.E. and Curtin, D. (2008) Efficiency of Soil and Fertilizer Phosphorus Use. Reconciling Changing Concepts of Soil Phosphorus Behaviour with Agronomic Information. FAO Fertilizer and Plant Nutrition Bulletin 18. Food Agricultural Organization of the United Nations, Rome.

[23] Fixen, P., Brentrup, F., Bruulsema, T., Garcia, F., Norton, R. and Zingore, S. (2015) Nutrient/Fertilizer Use Efficiency: Measurement, Current Situation and Trends. In: Managing Water and Fertilizer for Sustainable Agricultural Intensification, International Fertilizer Industry Association (IFA), International Water Management Institute (IWMI), International Plant Nutrition Institute (IPNI), and International Potash Institute (IPI), Paris, Chapter 2, 8-38.

[24] Olsen, S., Cole, C., Watanabe, F. and Dean, L. (1954) Estimation of Available Phosphorus in Soils by Extraction with Sodium Bicarbonate, Circular 939, U.S. Department of Agriculture, Washington DC.

[25] Deshpande, V.V. and Telang, M.S. (1950) Pipet Method of Sedimentation Analysis. Rapid Determination of Distribution of Particle Size. Analytical Chemistry, 22, 840-841. https://doi.org/10.1021/ac60042a033

[26] Walkley, A. and Black, I.A. (1934) An Examination of the Degtjareff Method for Determining Soil Organic Matter, and a Proposed Modification of the Chromic Acid Titration Method. Soil Science, 37, 29-38. https://doi.org/10.1097/00010694-193401000-00003

[27] Murphy, J. and Riley, J. (1962) A Modified Single Solution Method for the Determination of Phosphate in Natural Waters. Analytica Chimica Acta, 27, 31-36. https://doi.org/10.1016/S0003-2670(00)88444-5

[28] ISO 11466 (1995) Soil Quality-Extraction of Trace Elements Soluble in Aqua Regia.

[29] Möller, K. (2016) Assessment of Alternative Phosphorus Fertilizers for Organic 
Farming: Compost and Digestates from Urban Organic Wastes. Fact Sheet. FIBL, Universitat Hohenheim, ETH Zurich, Newcastle University, University of Copenhagen, Bioforsk, Universität für Bodenkultur Wien.

[30] Teglia, C., Tremier, A. and Martel, J.-L. (2011) Characterization of Solid Digestates: Part 2, Assessment of the Quality and Suitability for Composting of Six Digested Products. Waste and Biomass Valorization, 2, 113-126. https://doi.org/10.1007/s12649-010-9059-x

[31] Möller, K., Stinner, W., Deuker, A. and Leithold, G. (2008) Effects of Different Manuring Systems with and without Biogas Digestion on Nitrogen Cycle and Crop Yield in Mixed Organic Farming Systems. Nutrient Cycling in Agroecosystems, 82, 209-232. https://doi.org/10.1007/s10705-008-9196-9

[32] Zeng, Y., De Guardia, A. and Dabert, P. (2016) Improving Composting as a PostTreatment of Anaerobic Digestate. Bioresource Technology, 201, 293-303. https://doi.org/10.1016/j.biortech.2015.11.013

[33] Pötsch, E.M. (2005) Nutrient Content of Fermentation Residues from Agricultural Biogas Systems and Their Utilization on Permanent Grassland. Final Report, 32.

[34] Voca, N., Kricka, T., Cosic, T., Rupic, V., Jukic, Z. and Kalambura, S. (2005) Digestate Residue as a Fertilizer after Mesophilic Process of Anaerobic Digestion. Plant, Soil and Environment, 51, 262-266. https://doi.org/10.17221/3584-PSE

[35] Kluge, R., Wagner, W., Mokry, M. and Dederer, M. (2008) Final Report of the Project Inhaltsstoffe von Garprodukten und Moglichkeiten $\mathrm{zu}$ ihrer geordneten landwirtschaftlichen Verwertung.

[36] Möller, K., Schulz, R. and Müller, T. (2010) Substrate Inputs, Nutrient Flows and Nitrogen Loss of Two Centralized Biogas Plants in Southern Germany. Nutrient Cycling in Agroecosystems, 87, 307-325. https://doi.org/10.1007/s10705-009-9340-1

[37] Ayers, R.S. and Westcot, D.W. (1985) Water Quality for Agriculture. FAO Irrigation and Drainage Pap. 29, Rev. 1. FAO, Rome.

[38] Pötsch, E.M., Pfundtner, E. and Much, P. (2004) Nutrient Content and Hygienic Properties of Fermentation Residues from Agricultural Biogas Plants. Proceedings of the 20 th General Meeting of the European Grassland Federation, Luzern, 21-24 June 2004, 1055-1057.

[39] Decret Law 103 (2015) Decreto Lei 103/2015, Diário da República, $1^{\text {a }}$ série no $114-15$ junho de 2015.

[40] AFNOR: FD CR 13456 (2001) Amendments du sol et supports de culture-Etiquetaje, spécifications et listes de produits.

[41] Siebert, S. (2008) Quality Requirements and Quality Assurance of Digestion Residuals in Germany. ECNIORBIT Workshop the Future for Anaerobic Digestion of Organic Waste in Europe, Nuremberg.

http://www.kompost.de/uploads/media/Quality_Requirements_of_digestion_residu als_in_Germany_text_01.pdf

[42] AFNOR: NF U44-051 (2006) Amendments organiques-Dénominations, specifications et marquage.

[43] Goyal, S., Dhull, S.K. and Kapoor, K.K. (2005) Chemical and Biological Changes during Composting of Different Organic Wastes and Assessment of Compost Maturity. Bioresource Technology, 96, 1584-1591. https://doi.org/10.1016/j.biortech.2004.12.012

[44] Mangkoedihardjo, S. (2006) Revaluation of Maturity and Stability Indices for Compost. Journal of Applied Sciences and Environmental Management, 10, 83-85. 
https://doi.org/10.4314/jasem.v10i3.17324

[45] Horta, C. (2019) Fertilisation with Compost: Effects on Soil Phosphorus Sorption and on Phosphorus Availability in Acid Soils. Open Journal of Soil Science, 9, 255-268. https://doi.org/10.4236/ojss.2019.912016

[46] Nziguheba, G., Palm, C.A., Buresh, R.J. and Smithson, P.C. (1998) Soil Phosphorus Fractions and Adsorption as Affected by Organic and Inorganic Sources. Plant and Soil, 198, 159-168. https://doi.org/10.1023/A:1004389704235

[47] Nest, T.V., Ruysschaert, G., Vandecasteele, B., Houot, S., Baken, S., Smolders, E., Cougnon, M., Reheul, D. and Merckx, R. (2016) The Long Term Use of Farmyard Manure and Compost: Effects on P Availability, Orthophosphate Sorption Strength and P Leaching. Agriculture, Ecosystems and Environment, 201, 23-33. https://doi.org/10.1016/j.agee.2015.09.009

[48] Rashmi, I., Parama, V.R.R. and Biswas, A.K. (2016) Phosphate Sorption Parameters in Relation to Soil Properties in Some Major Agricultural Soils of India. SAARC Journal of Agriculture, 14, 1-9. https://doi.org/10.3329/sja.v14i1.29549

[49] Albuquerque, J.A., de la Fuente, C. and Bernal, M.P. (2012) Chemical Properties of Anaerobic Digestates Affecting C and N Dynamics in Amended Soils. Agriculture, Ecosystems and Environment, 160, 15-22. https://doi.org/10.1016/j.agee.2011.03.007

[50] de la Fuente, C., Alburquerque, J.A., Clemente, R. and Bernal, M.P. (2013) Soil C and $\mathrm{N}$ Mineralisation and Agricultural Value of the Products of an Anaerobic Digestion System. Biology and Fertility of Soils, 49, 313-322.

https://doi.org/10.1007/s00374-012-0719-9 